behalf of the Swedish authorities or whether his comments were entirely his own. There were 97 reports, including 40 cases of bleeding or perforation. The largest number with any of the nine other non-steroidal anti-inflammatory drugs was six, and there were no reports for diflunisal, phenylbutazone, or oxyphenbutazone. At first sight, serious complications appear to be many times more frequent with piroxicam. It is very dangerous, however, to make comparisons of this kind from anecdotal reporting. In this case, it seems very likely that there is a large relative deficit of reports on the older non-steroidal antiinflammatory drugs.

We shall shortly be publishing the preliminary results of a study of more than 50000 patients treated with benoxaprofen, fenbufen zomepirac, indomethacin, or piroxicam. It covered a period equivalent to about 90000 patient years of observation, about half during and half after stopping or changing treatment. The frequency of upper gastrointestinal bleeding or perforation ranged from three to six cases per 1000 patient years, only a minority being attributed to the non-steroidal anti-inflammatory drug by the reporting doctor. Our data suggest that these events occurred with equal frequency after the patients had stopped or switched non-steroidal antiinflammatory drugs and were very rarely caused by these drugs. It is extremely unlikely that piroxicam could be so much more dangerous than other non-steroidal anti-inflammatory drugs. Using "defined daily dose" as a crude measure of drug use in Sweden the 40 cases of bleeding could correspond to a rate of about one case per 1000 patient years of use of piroxicam. This is lower than the rate in any of our five groups, whether the patients were taking a non-steroidal anti-inflammatory drug or not.

Spontaneous reporting to national monitoring centres provides useful internal alerting signals which sometimes indicate the need for further research. The data cannot be used to produce estimates of incidence and must not be used as the sole basis for regulatory action. Publications about the alleged side effects of new drugs have a "bandwagon" effect on reporting and, if taken up by the media, can be very damaging to patients' confidence in treatment. Several questionable regulatory decisions have recently been forced on the authorities by publicity of this kind.

W H W INMAN N S B RAWSON

Drug Surveillance Research Unit, University of Southampton, Southampton $\mathrm{SO} 32 \mathrm{BX}$

\section{Threat to the PHLS}

SIR,-I have read with great interest the article by Sir James Howie (23 February, p 579) and am giateful to him for his clear exposition of the difficulties that the PHLS has had to meet. I do not agree with his remedy. I feel that the full story of the formation of the PHLS should be told.

I was appointed principal officer of the medical services of Bristol City Council in June 1930. At that time many infectious diseases were prevalen in the city-diphtheria, tuberculosis, and intestinal infections such as typhoid and dysentery. The city council was responsible for maintaining a vigilant port health service at Portishead, Avonmouth, and Bristol to safeguard the country against the introduction of dangerous infections from other coun- tries, such as plague, smallpox, cholera, and typhus fever. There was also the requirement to preven contaminated and unfit foodstuffs from entering the country. For these purposes the city had to employ properly trained doctors, health inspectors, and health visitors as field officers, and the medical officer of health and his deputy became responsible for admissions to an infectious disease hospital with its own specialists. To aid in the preliminary diagnosis a laboratory service had to be available. This was provided by Professor Walker Hall, who was professor of pathology at the university. The chemical laboratory service was provided by the public analyst.

Professor Walker Hall felt that a scheme was needed for the growing service. We presented to the city council and the university a joint scheme in which Professor Walker Hall would be the full time director of the new public health laboratory. The project was to be administered by the university and housed in a suitably converted building. The city's principal medical officer became the professor of preventive medicine (honorary) and brought in field officers available from the corporation. The whole cost fell on the city council.

The scheme was adopted and it brought the university and city council closer together. It worked admirably for some years and we were able to help adjacent health authorities with some of their problems. The Minister of Health (Sir Hilton Young) came to inaugurate the scheme. It came to the notice of the Rockefeller Foundation and they sent Dr Fitzgerald from Toronto and the professor of public health, University of California, to see and report.

After the war it became the fashion to regard big as beautiful. Never mind the results; to be efficient it had to be big. Politicians were determined to introduce a National Health Service administered from London. Some of us, led by Sir Frederick Menzies, wanted slow evolution and progress.

Drs Topley and Wilson argued for a PHLS for the whole country administered from London and visualised the good points of the idea quoted by Sir James. I remained convinced that the public health laboratory was a necessary instrument for an efficient local public health service administered by a properly appointed local health authority with a specially qualified doctor as the administrator.

The public health service of Bristol had taken 100 years to develop and had the full support of its half a million population and its city council. How it grew during this period is recorded in the annual reports of the medical officers of health. I was medical officer of health for 25 years and was very proud of its achievements. The changing order took but a few years to smother our efforts to progress. The preventive medicine department we established had virtually disappeared.

I never thought that I should survive to my 90th year to see a glimmer of hope for a new and local public health service with its own laboratory service and a medical officer reporting to a local public health committeea service built on the foundations laid by such giants as Sir John Simon, Sir Arthur Newsome, and Sir George Newman.

Criccieth,

Robert Hughes PARRy

Gwynedd LL52 0TB

SIR,-It is indeed a sorry state of affairs when Sir James Howie has to write as he did regarding the threat to the public health laboratory service. As an ex-service doctor I was among the first postgraduate public health students to be specifically trained for the concepts of the coming NHS, one of the pillars of which was to be a much strengthened approach to epidemiology. The Brighton health department was early involved in the international typhoid outbreak, which the PHLS firmly demonstrated to an incredulous Swiss government as emanating from Zermatt and which put over 1000 of our own citizens at risk. Later my deputy, with the collaboration of the PHLS, was able to identify the Russian tourist links with foci of lambliasis. The definitive 1959 research on coastal pollution, which coordinated studies at 83 seaside resorts, also comes to mind. A few years ago Lassa fever was a countrywide threat, against which this nationally coordinated laboratory service was our only shield. In nearly 70 separate episodes of imported suspect smallpox in which I was involved as a consultant to the Ministry of Health the PHLS was an essential support service for diagnosis and epidemiology. One can imagine the reaction there would have been then if we had had positive cases and the politicians had suggested abolishing the service.

This mention of some of the highlights of the value of a service with which I was in daily personal collaboration in my own practice of public health can be echoed by the experiences of my colleagues throughout the country. The cost of the continuation of the Public Health Laboratory Service is a very small premium to pay for an essential insurance for the future. I trust that all those with inner knowledge of the service will write personally to the Chief Medical Officer to urge its continuation.

Brighton BN1 8TD

W S PARKeR

\section{Platelets and coronary disease}

SIR,- "We dispense with precision" was the unfortunate claim of the village pharmacy. So does Professor J R Hampton in his leading article (9 February, p 414) about our report on platelet aggregability (p 428).

It is not clear what point Professor Hampton wanted to make. It seems he has assumed that we accept both the generally held view about platelet function in ischaemic heart disease and the validity of the adenosine diphosphate ED50 measure of this function. If so, he has misrepresented us. There were several quite unexpected findings in our data. Professor Hampton glossed over one of the most obvious anomalies by saying that aggregability was "not increased by smoking" when in fact it was significantly less in smokers.

Professor Hampton concluded that until there is a convincing trial of a platelet active agent there is no reason to believe that platelet function tests are of "any importance at all" in vascular disease. (He did not mention the striking effect of aspirin in unstable angina. ${ }^{1}$ ) However, his own preconditions did not stop him giving his opinion on a variety of measurements. The evidence for his views comes from small studies after myocardial infarction. We have preferred to establish, first, the epidemiological characteristics of what has so far been one of the most widely used indices and, in due course, the prospective relation between this index and the risk of ischaemic heart disease in those previously free of clinical manifestations. Until the latter relation, in particular, is clear the value of our technique and of Professor Hampton's preferred methods are open to questions. Within the field of arterial disease, identifying a valid index of platelet function is particularly difficult and will not be achieved by speculating about which measurements "are probably more useful."

Professor Hampton alludes to the possibility of a plasma factor influencing platelet response to adenosine diphosphate. $\mathrm{He}$ did not refer to 
fibrinogen, which our data strongly suggest may act in this way. This finding may imply that platelets play a less active part in thrombogenesis than is generally assumed, a possibility very recently also suggested by others. ${ }^{2}$

Our study is not one of cases and "healthy controls," as implied by Professor Hampton. It is based on defined occupational groups subject to the full range of conditions, vascular or otherwise, to be expected in the working populations concerned. Where cases and controls are used the non-specific effects of a range of illnesses besides coronary disease should be allowed for. ${ }^{3}$ May I urge readers who want to know what we actually said and concluded to rely on our paper rather than Professor Hampton's review?

\section{T W MEADE}

MRC Epidemiology and Medical Care Unit, Northwick Park Hospital,

Harrow HA1 3U

1 Lewis DH, Davis JW, Archiblad DG, et al. Protective effects of aspirin against acute myocardial infarction and death in men with unstable angina. $N$ Engl $f$ Med 1983;309:396-403.

2 Lowe GDO, Forbes CD. Platelet aggregation, haematocrit, and fibrinogen. Lancet 1985;i:395-6.

3 Lowe GDO, Reavey MM, Johnston RV, et al. Increased platelet aggregates in vascular and nonvascular illness: correlation with plasma fibrinogen

***Professor Hampton replies below.-ED, $B M F$.

SIR,-I find Dr Meade's letter as incomprehensible as he evidently found my leading article, but it is clear that I can teach him nothing about the art of misquotation. Our fundamental disagreement is presumably about the purpose of leading articles in general : in my view they are not meant to be simply the publication of a referee's opinion about a paper, but they are intended to set the findings of a paper within the general context of the problem to which the paper is addressed. A leading article is not a detailed review of a subject but is a selection of references, and the selection reflects the writer's opinion. In writing a leading article based on Dr Meade's paper, the point I wanted to make was that (in my opinion) 25 years of platelet function testing has not led us very much closer to the secrets of clinical thrombosis.

However, I am happy here to take up one or two of Dr Meade's specific points. The evidence seems to be quite clear that if there is a platelet function test that has anything to do with clinical thrombosis it is one that is related to the second phase of adenosine diphosphate induced platelet aggregation. Evidence continues to accumulate to this effect, $^{1}$ and if aspirin does indeed have any beneficial clinical effect then we must remember that it is the second phase of platelet aggregation that is influenced by aspirin. Dr Meade's ED50 method relates to the first phase of aggregation, and if one were now setting out to do an epi-

Time dependent venous haemoconcentration during occlusion of upper arm in 10 young (age 21-27), male, healthy volunteers. Results are means (and standard deviations)

Occlusion of upper arm at $40 \mathrm{~mm} \mathrm{Hg}$ for (minutes):

\begin{tabular}{|c|c|c|c|c|}
\hline Variable (and method) & 0 & 1 & 2 & 3 \\
\hline $\begin{array}{l}\text { Packed cell volume ( }{ }^{\circ} \text { ) (centrifuge) } \\
\text { Haemoglobin (g/l) (photometry) } \\
\text { Fibrinogen (g/1) (Clauss) } \\
\text { Plasma viscosity (mPa s) (Harkness) }\end{array}$ & $\begin{array}{l}44(2) \\
16 \cdot 8(0 \cdot 9) \\
2 \cdot 9(0 \cdot 7) \\
1 \cdot 12(0 \cdot 05)\end{array}$ & $\begin{array}{l}45(2) \\
17 \cdot 6(1 \cdot 1) \\
3 \cdot 1(0 \cdot 8) \\
1 \cdot 13(0 \cdot 05)\end{array}$ & $\begin{array}{l}46(3) \\
18 \cdot 2(1 \cdot 9) \\
3 \cdot 2(1 \cdot 0) \\
1 \cdot 15(0 \cdot 09)\end{array}$ & $\begin{array}{l}46(4) \\
20 \cdot 4(2 \cdot 4) \\
3 \cdot 4(1 \cdot 0) \\
1 \cdot 18(0.08)\end{array}$ \\
\hline $\begin{array}{l}\text { Colloidosmotic pressure }(\mathrm{mm} \mathrm{Hg}) \text { (semipermeable } \\
\text { membrane) } \\
\text { Serum cholesterol }(\mathrm{mmol} / \mathrm{l})\end{array}$ & $\begin{array}{r}24 \cdot 6(1 \cdot 5) \\
3 \cdot 1(0.6)\end{array}$ & $\begin{array}{r}27.0(1.4) \\
3.4(0.7)\end{array}$ & $\begin{array}{r}29.3(1.9) \\
3.7(0.7)\end{array}$ & $\begin{array}{r}31 \cdot 7(2 \cdot 6) \\
4 \cdot 2(1 \cdot 1)\end{array}$ \\
\hline
\end{tabular}

discuss the possible importance of fibrinogen as a major determinant of platelet behaviour, but he has clearly forgotten that the unidentified factor that affected the platelet electrophoretic response to adenosine diphosphate, which was apparently closely related to vascular disease, was a phospholipid and was certainly not fibrinogen.

(In my opinion) a quarter of a century of studying platelets has taught us a lot about platelet physiology but not much about coronary disease. There was nothing in $\mathrm{Dr}$ Meade's paper, or in his letter, to make me change my mind.

Department of Medicine,

Queen's Medical Centre,
Nottingham NG7 2UH

1 Vilen L, Johansson S, Kutti J, et al. ADP-induced platelet aggregation in young female survivors of trols. Acta Med Scand 1985;217:9-13.

SIR,-Please allow us to comment on one aspect of the recent update of the excellent Northwick Heart Study by Dr T W Meade and others: "Blood was taken without venecompression unless otherwise unobtainable." This statement, reflecting pure common sense and being part of almost any epidemiological study (if honest and well written), may bear more relevance than it seems at first glance. During venous occlusion there is a rapid, time dependent loss of intravascular fluid from the veins into the extravascular space, leading to a concentration of blood cells and plasma proteins, protein bound substances such as calcium, magnesium, ${ }^{1}$ trace elements, ${ }^{2}$ and other molecules like cholesterol. ${ }^{3}$ Our own experiments show this phenomenon through a rise in packed cell volume, plasma viscosity, plasma colloid osmotic pressure, and cholesterol during venous obstruction with a $40 \mathrm{~mm} \mathrm{Hg}$
cuff (see table). This could mean that packed cell volume and haemoglobin, fibrinogen, lipoprotein concentrations, etc, are falsely found to be high in individuals presenting with "bad veins" (not easy to puncture, hence the necessity of longer occlusion). Precisely these factors have been repeatedly shown to be predictive of cardiovascular risk. ${ }^{4-6}$ We know of no study correlating "vein quality" with the cardiovascular risk. Neither are we in the least proposing this as a sole factor. Such an association (bad veins, long venous compression, higher values with several blood tests, bad prognosis) might, however, be superimposed on the results of many epidemiological trials.

This would seem to make sense in evolutionary terms, in respect of the above mentioned studies and the aforementioned theoretical argument. Furthermore, it does not seem to contradict clinical experience. At present we are investigating this potentially important problem in a large population based study.

Haemorheology Research Laboratory,

A Matral E ERNST

Clinic for Physical Medicine,

8000 München 2, FRG

1 Menayr P, Nielsen SL, Christiansen C, Axelsson C. Gross errors made by routine blood sampling from two sides using a tourniquet applied at differen positions. Clin Chem Acta 1979;198:113-8. Milne DB. The effect of temporary venous occlusion on trace mineral concentrations in plasma $A m$ sion on trace mineral conce
$\exists$ Clin Nutr $1982 ; 36: 354$

Stateland BE, Winkel P. Variations of cholesterol and total lipid concentration of healthy young men. Differentiating analytic error from biologic variability. Am f Clin Pathol 1976;66:935.

4 Sorlie PD, Garcia-Palmiere MR, Costas R, Havlik RJ. Hematocrit and the risk of coronary heart disease The Puerto Rico Heart Program. Am Heart $\mathcal{F} 1981$;

Wilhelmsen L, Svärdsudd K, Korsan-Bengtsen $K$, Larsson B, Welin L, Tibblin G. Fibrinogen as a risk factor for stroke and
$N$ Engl $\mathcal{F}$ Med $1984 ; 311: 501$.

6 Levy RJ, Bensike JF, Epstein SE, et al. The influence of changes in lipid values induced by cholestyra mine and diet on progression of coronary artery disease: results of the NHLBJ Type II coronary intervention study. Circulation 1984;69:325.

\section{The need for sexual assault centres in the UK}

SIR,-I was delighted to see Dr May Duddle's article on the need for sexual assault centres in the UK (9 March, p 771) and I hope that as a result of this some progress will actually be made.

In the matter of rape there are two major problems. The first is that many women do not report to the police and do not know where to get help. This means that perpetrators of rape are being allowed to get away with their crimes and no doubt to repeat them with impunity. It also means that the women concerned may not get the help they need and this will surely lead to future morbidity in some cases.

The second problem is the number of women who do report to the police that they have been raped and then withdraw the allegation. In some cases they have been raped but feel unable to go on with the investigation, and this is understandable when the reality of a rape trial is considered. The woman is on her own in court on trial in fact, though not in law, and the object of the defence is to discredit her.

However, there is a further even more difficult problem, and that is the number of cases which turn out to be completely unfounded. In 1984 I saw 37 cases of alleged rape at the request of the police and 12 of these have been proved to be unfounded. One was a woman who had been drinking after attending the 